\title{
Infrared spectroscopy analysis on charcoal generated by the pyrolysis of Corymbia citriodora wood
}

\section{Análise da espectroscopia de infravermelho em carvão vegetal produzido pela pirólise da madeira de Corymbia citriodora}

Ananias Francisco Dias Júnior ${ }^{1}$, Renata Nunes de Oliveira ${ }^{2}$, Xavier Deglise ${ }^{3}$, Natália Dias de Souza ${ }^{2}$, José Otávio Brito ${ }^{4}$

\author{
${ }^{1}$ University of Espírito Santo - DCFM/UFES, CEP: 29550-000, Jerônimo Monteiro, Espírito Santo, Brazil. \\ ${ }^{2}$ Federal Rural University of Rio de Janeiro - UFRRJ, CEP: 23890-000, Seropédica, Rio de Janeiro, Brazil. \\ ${ }^{3}$ Université Henri Poincaré, CP: 23954506, Vandoeuvre, France. \\ ${ }^{4}$ University of São Paulo - ESALQ/USP, CEP: 13418-900, Piracicaba, São Paulo, Brazil. \\ e-mail: ananiasjr@usp.br, renatanunes.ufrrj@gmail.com, deglise@lermab.uhp-nancy.fr, natdias@hotmail.com, jobri- \\ to@usp.br
}

\begin{abstract}
Wood pyrolysis has been use for centuries to obtain charcoal. Nonetheless, the study of wood components altering by the pyrolysis temperature is crucial to determine the charcoal's properties. The present research aims to evaluate by FTIR the chemical altering of wood submitted to various pyrolysis temperatures. Samples of Corymbia citriodora species were submitted to temperatures of $240{ }^{\circ} \mathrm{C}, 280{ }^{\circ} \mathrm{C}, 320{ }^{\circ} \mathrm{C}$ and $400{ }^{\circ} \mathrm{C}$ in a fixed bed reactor filled with $\mathrm{N}_{2}$. The FTIR analysis was performed in the wood residues after pyrolysis. The results showed that cellulose and hemicelluloses presented more susceptibility to thermal degradation than other wood components. It could be observed chemical altering in the wood residue obtained between $240{ }^{\circ} \mathrm{C}$ and $280{ }^{\circ} \mathrm{C}$. In addition, the wood residue obtained for treatments over $280{ }^{\circ} \mathrm{C}$ presented characteristics similar to vegetal charcoal. There are a continuous change of the wood due to the temperature of the pyrolysis by the change of bands intensity and by the bands shift. The FTIR analysis allowed the evaluation of the wood's pyrolysis process and its chemical variations with the temperatures applicate.
\end{abstract}

Keywords: thermal degradation, wood, FTIR.

\section{INTRODUCTION}

Wood has been used as a primary source of energy and of chemicals for centuries. Nonetheless, wood has been replaced by vegetal charcoal since the beginning of the $19^{\text {th }}$ century and after that, oil and its derivatives were also used as an energy source. In the 70's, due to the first glimpses of oil depletion and of energy crises, wood thermal processes regain the Energy industry's interest, specially pyrolysis and carbonization.

The pyrolysis process intends to eliminate part of the wood components by thermal degradation, concentrating carbon in the residue. The pyrolysis process results in formation of bonds between carbons, where cyclic and/or aromatic structures are formed with the temperature rise [1,2]. These carbon structures are characterized by different degrees of aromaticity and they are the main carbon chains of vegetal charcoal. According to the environment in which the charcoal is placed, these chains can remain intact for centuries and they act as carbon dissipater, absorbing/binding the $\mathrm{CO}_{2}$ emitted to the atmosphere $[3,4]$.

Charcoal is used in several applications, but it does not present a set composition, which difficult its application. Studies related to vegetal charcoal's composition, structures and properties are sparse [4]. There are various properties related to vegetal charcoal that remain not completely explained due to the difficulties to set its composition, e.g. charcoal's adsorption and hygroscopic ability [5, 6], direct combustion property [7], aromatic elements emission due to combustion [8,9]. Charcoal groups different carbon components, presenting a variety of degrees of complexity, which characterization demands time and high cost. Its characterization can be partially done by quick methods which require none or few samples' preparation, but these are insufficient to the complete understand the structure and characteristics of the vegetal charcoal [4]. 
Methodologies based on vibrational spectroscopy are alternative methods to traditional physicchemical techniques $[4,10]$. The Fourier Transformed Infrared Spectroscopy - FTIR uses infrared radiation, which is located in the wavelength region between visible light and microwaves. The infrared radiation is characterized by three regions: near infrared (from $4000 \mathrm{~cm}^{-1}$ to visible light wavenumber); medium infrared (between $400 \mathrm{~cm}^{-1}$ and $4000 \mathrm{~cm}^{-1}$ ), which is the wavelength where the vibration of the bonds related to organic compounds occur; and distant infrared (from $400 \mathrm{~cm}^{-1}$ to microwave) [11]. Complementary information regarding functional groups can be provided by FTIR technique, while Raman Spectroscopy can detail information regarding aliphatic and aromatic groups. FTIR analysis has been used to characterize the biochar structure, which is used in soils. FTIR and Raman techniques are complementary; both provide functional groups information, since aromatic bonds presenting different degrees of substitution respond directly to FTIR $[10,12]$.

The organic part of charcoal is composed mainly by two groups of compounds: aromatic and hydroaromatic compounds and alkyl bridges, ether or thioether linkages that connect the aromatic compounds. The "drag" phases involved in the process of obtaining charcoal would be hydrocarbons and aliphatic and aromatic compounds. The charcoal composition varies according to the charcoal's origin and biogeochemical processes [13].

Cademartori et al. [14] investigated the changes of Eucalyptus wood submitted to thermal treatment $\left(180-240{ }^{\circ} \mathrm{C}\right)$ for $4 \mathrm{~h}$ and they observed the degradation of hemicelluloses and a decrease of wood's hygroscopicity and mechanical strength. Esteves et al. [15] evaluated the changes in Eucalyptus and Pinus wood species submitted to thermal treatment between $170{ }^{\circ} \mathrm{C}$ and $210{ }^{\circ} \mathrm{C}$ for $2 \mathrm{~h}$ and they concluded that the thermal treatment degraded the hemicelluloses and it altered mainly the structure of wood's lignin and amorphous cellulose. In addition, the authors highlight that it is difficult to monitor the wood changes due thermal treatment by FTIR, since various chemical reactions occur simultaneously [15]. The wood of Pinus sylvestris, Fagus orientalis and Picea orientalis heat treated between $190{ }^{\circ} \mathrm{C}$ and $212{ }^{\circ} \mathrm{C}$ by FTIR and they observed the degradation of hemicelluloses and of amorphous cellulose and altering in the carbohydrate and lignin compounds depending on the wood species [16]. The objective of the present research is to evaluate by medium infrared spectroscopy the Corymbia citriodora wood's chemical compounds altering due to thermal treatment of pyrolysis, according to the FTIR absorption bands after thermal treatment under different temperatures.

\section{MATERIAL AND METHODS}

The wood used in this work was obtained from a plantation of Corymbia citriodora, age of 6.5 years, from São Paulo, Southwest of Brazil. Measurement of basic density was performed according to standard NBR 11941[17]. The TAPPI standard [18] and the TAPPI standard [19], respectively, were used to determine the total extractive and lignin Klason contents. Holocellulose content was obtained indirectly by subtracting the sum of total extractive contents and lignin content of $100 \%$. The ash content were determined according to ASTM D-1764 [20].

Wood samples were prepared initially by cutting the wood into cubes of $27 \mathrm{~cm}^{3}$. The samples were dried in an oven at $103{ }^{\circ} \mathrm{C} \pm 2{ }^{\circ} \mathrm{C}$, and the drying was finished when the samples reached constant mass. Then, the cubes (samples) were submitted to pyrolysis in a fixed bed reactor saturated of $\mathrm{N}_{2}$. The mass of the samples used in each pyrolysis test was $300 \mathrm{~g}$, where the samples were heated at a rate of $4{ }^{\circ} \mathrm{C} \mathrm{min}^{-1}$. The pyrolysis analysis occurred at different temperatures, and after stabilization, the samples remained at the final temperature for $60 \mathrm{~min}$. The final temperatures were $240{ }^{\circ} \mathrm{C}, 280{ }^{\circ} \mathrm{C}, 320^{\circ} \mathrm{C}$ and $400{ }^{\circ} \mathrm{C}$. The process' yield of a solid material was determined according to Equation 1, where 'SMY' is the solid material yield; 'Mc' is the mass of charcoal (g); 'Mw' is the mass of dry wood (g).

$$
\operatorname{SMY}(\%)=\frac{\mathrm{Mc}}{\mathrm{Mw}} \times 100
$$

The analysis of the chemical compounds' bonds vibration of the in nature wood and of the wood submitted to the pyrolysis processes was performed by FTIR, Perkin Elmer equipment, diffuse reflectance mode, resolution of $4 \mathrm{~cm}^{-1}, 128$ scans per samples, wavenumber range of $\left(4000-400 \mathrm{~cm}^{-1}\right)$. In order to do so, the samples were lyophilized and $2 \mathrm{mg}$ of the samples were mixed with $\mathrm{KBr}$ and pressed into pallets, which were analyzed by FTIR. 


\section{RESULTS AND DISCUSSION}

The Corymbia citriodora wood presented the following characteristics: density of $0.630 \mathrm{~g} \mathrm{~cm}^{-3}$; total extractive content of 19\%; Klason lignin content of $19 \%$; holocellulose content of $74 \%$; ash content of $1,10 \%$. The total ash content is approximately the same of the Brazilian Eucalyptus species studied by Poletto et al. [21], $(1.1 \pm 3) \%$, although these authors found lower amounts of holocellulose and extractives and higher amounts of lignin in their Eucalyptus species [21]. The basic density, which indicates the quality of the wood, where the denser the wood, higher the charcoal yield, presented a high value for an eucalyptus species [22].

The charcoal yield as solid material can be observed in Figure 1, where the charcoal yield diminishes with rise of the pyrolysis' temperature. The pyrolysis yield of wood for heat treatment at 240, 280, 320 and $400{ }^{\circ} \mathrm{C}$ was $78,59,47$ and $34 \%$, respectively. High temperatures degrade the wood effectively, nonetheless there is also a high evolution of mobile phases, condensable or non-condensable gases [23].

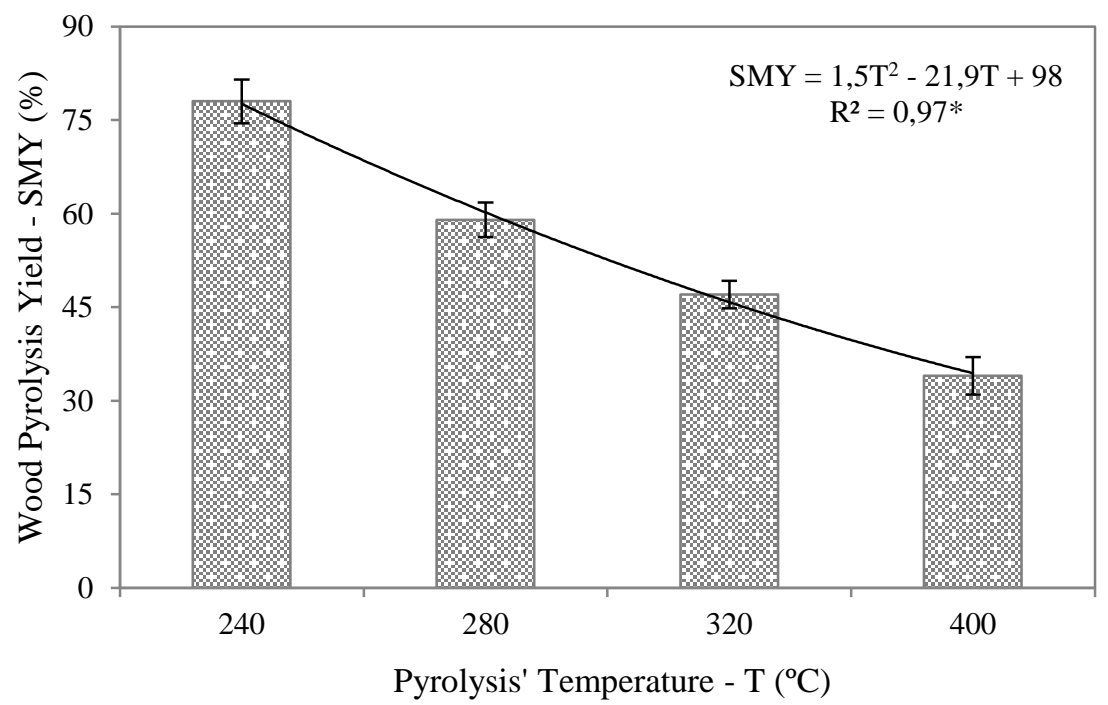

Figure 1: Yield of wood pyrolysis. Significant at $95 \%$ probability $(\mathrm{p}<0,05)$.

The thermal degradation of wood begins at low temperatures, approximately $200{ }^{\circ} \mathrm{C}$. In controlled environment, free of oxygen, there is the beginning of the charcoal formation. The wood's complete conversion into charcoal also depends on remaining time inside of the reactor, heating rate, pyrolysis process' methodology, raw material [23, 24, 25].

The FTIR analysis was performed to determine the bands related to the solid material (charcoal) after the pyrolysis treatment, to identify the chemical groups remaining in charcoal or formed after the thermal treatment. The FTIR spectra of in nature wood and charcoal after the four thermal treatments are displayed in Figure 2 and Table 1, and it is worth noticing that FTIR spectra of charcoal usually present broad bands [4]. The charcoal obtained from at $240{ }^{\circ} \mathrm{C}$ presented spectrum similar to the original wood, where changes were observed for samples treated at $280{ }^{\circ} \mathrm{C}$ or higher temperatures. 

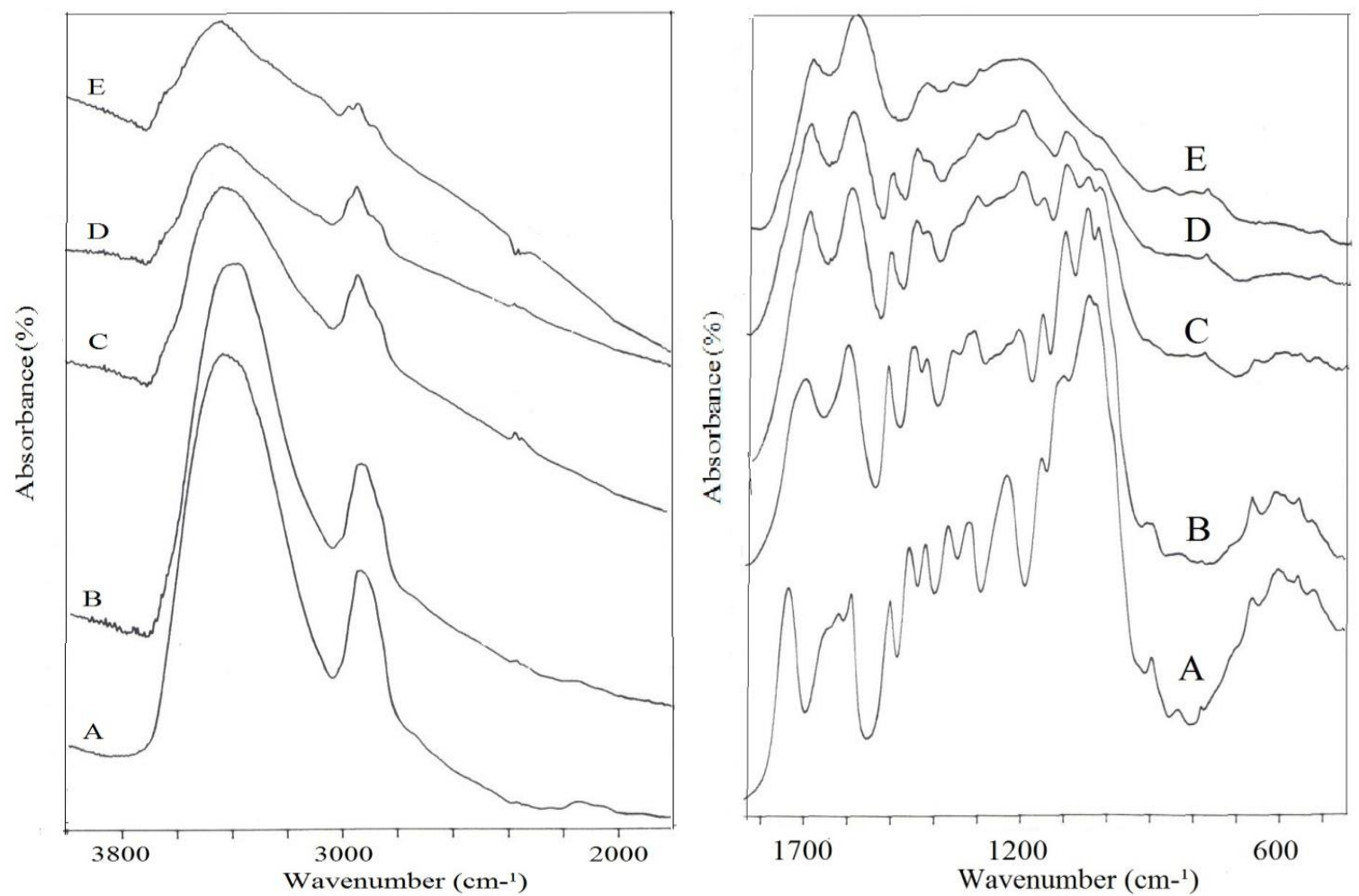

Figure 2: Infrared spectra of the bands 4000 a $450 \mathrm{~cm}^{-1}$, where A is related to the in nature wood; and B, C, D and E spectra are related to the thermal treated wood at $240{ }^{\circ} \mathrm{C}, 280{ }^{\circ} \mathrm{C}, 320{ }^{\circ} \mathrm{C}$ and $400{ }^{\circ} \mathrm{C}$, respectively.

The intensity of the bands at $3420 \mathrm{~cm}^{-1}$ and at $2930 \mathrm{~cm}^{-1}$ diminished with the increase of the temperature of the pyrolysis (Figure 2). These bands are mainly related to $\mathrm{OH}, \mathrm{CH}_{3}, \mathrm{CH}_{2}$ and $\mathrm{CH}$ groups and the diminish of the bands can be related to the degradation of hemicelluloses [26]. These bands broadening and low intensity with the increase of the pyrolysis temperature can be attributed to the loss of water impregnated in the cell wall of wood and to the oxidation or hydrolysis of $\mathrm{OH}$ groups of hemicelluloses, that contributes to the increase of carboxylic acids [15, 27]. At high pyrolysis temperature, different absorption bands can be distinguished around $3000 \mathrm{~cm}^{-1}$, related to aromatic carbons, which can be due to chemical reactions that generate aromatic byproducts, which is also related to the amount of lignin in the wood [28, 29]. In addition, the diminished intensity of the band at $2900 \mathrm{~cm}^{-1}$ can be attributed to cellulose's crystallinity altering, which influence the $v(\mathrm{C}-\mathrm{H})$ and $v(\mathrm{O}-\mathrm{H})$ bands intensity [30].

The in natura wood presented a band at $2865 \mathrm{~cm}^{-1}$, which is associated to the stretching $\mathrm{CH}_{3}$ of the lignin methoxyl groups $[31,32,33]$. This band can still be observed in the charcoal and, depending on the temperature of the pyrolysis, this band is more intense in the charcoal than in the wood itself. Regarding this band, Esteves et al. [15] observed this band was shifted towards low wavenumber after thermal treatment. Nonetheless, the results of the present study regarding this band indicates that cellulose and hemicelluloses degrade preferably when the wood is submitted to pyrolysis. According to the pyrolysis temperature, there is an angular deviation of the base line between $4000 \mathrm{~cm}^{-1}$ and $1900 \mathrm{~cm}^{-1}$. Usually, it occurs due to the presence of charcoal's organic or mineral byproducts [28, 29].

The band at $1740 \mathrm{~cm}^{-1}$ (Figure 2), is shifted towards low wavenumber and, with the increase of pyrolysis temperature, this band is less intense than in the wood and it gets broader, indicating that the $\mathrm{C}=\mathrm{O}$ groups are consumed during the wood pyrolysis and low amounts remain in the charcoal submitted to pyrolysis at high temperatures. The loss of intensity would be due to the cleavage of acetyl/acetoxy groups in xylan $[15,30]$.

The wood spectrum present one band around $1600 \mathrm{~cm}^{-1}$, where the vibration of the $\mathrm{C}=\mathrm{O}$ bonds of carboxyl acids and the vibration of ketones of lignin and hemicelluloses (bands at $1600 \mathrm{~cm}^{-1}$ and $1620 \mathrm{~cm}^{-1}$ ) are conjugated [14, 31, 32, 34, 35, 36, 37]. The difference of the bands of wood and the derived charcoal can be due to the degradation of bonds like $\mathrm{C}=\mathrm{C}$ or $\mathrm{COO}^{-}[28,29]$ and also due to the degradation of lignin [27]. The charcoal spectra present a high intense band at $1600 \mathrm{~cm}^{-1}$. It is attributed to the vibration of $\mathrm{C}=\mathrm{C}$ groups of aromatic rings, usually related to the presence of lignin and also to the formation of aromatic compounds originated by the elimination of hydrogen and oxygen of aliphatic compounds during the pyrolysis, where $250{ }^{\circ} \mathrm{C}$ is sufficient temperature to it [38]. 
The presence of a band at $1510 \mathrm{~cm}^{-1}(\mathrm{C}=\mathrm{C})$ also indicates the presence of an aromatic rings and this band occurs in the wood and charcoal obtained at temperatures between $240{ }^{\circ} \mathrm{C}$ and $380{ }^{\circ} \mathrm{C}$, but the charcoal obtained from a pyrolysis at $400{ }^{\circ} \mathrm{C}$ this band is not present, ensuring the degradation of lignin [27]. The bands at $1460 \mathrm{~cm}^{-1}$ and at $1425 \mathrm{~cm}^{-1}$ presented diminished intensity in charcoal and the last band was shifted towards $1450 \mathrm{~cm}^{-1}$. The low intensity of these bands in charcoal could be attributed to the loss of methoxyl groups (monomers) of lignin [30, 39]. Since the bands at $1375 \mathrm{~cm}^{-1}$ and at $1325 \mathrm{~cm}^{-1}$ are associated to C-H vibration, which occurs in several compounds of the wood, e.g. polysaccharides, hemicelluloses and lignin components, their intensity diminishes in charcoal due to the degradation of the wood components [15, 40].

The pyrolysis reduced the intensity of the bands at $1240 \mathrm{~cm}^{-1}$ and at $1110 \mathrm{~cm}^{-1}$. It occurs due to the loss of oxygenated groups and to the thermal degradation of these groups in hemicelluloses [28, 29, 41]. The first band could be associated to the guaiacyl lignin and to the syringyl lignin which is more susceptible to temperature and it can be eliminated during pyrolysis, reducing the band intensity in charcoal [16].

Mainly, all bands at wavenumbers lower than $1000 \mathrm{~cm}^{-1}$ are eliminated in charcoal with the increase of pyrolysis temperature. These bands would be related to cellulose and lignin and their decrease indicates the degradation of the wood components $[10,27]$.

\section{CONCLUSIONS}

The increase in pyrolysis temperature significantly decreased the yield of solid material from Corymbia citriodora wood.

It could be observed the continuous change of the wood due to the temperature of the pyrolysis by the change of bands intensity and by the bands shift.

Because bands of the FTIR analysis the charcoal pyrolyzed at $240{ }^{\circ} \mathrm{C}$ was similar to the original wood and for thermal treatments at higher temperatures the samples were closer to charcoal

\section{ACKNOWLEDGEMNT}

The authors would like to thank CAPES, IPEF, CNPq (142075/2016-7) and the Université Henry Poincaré.

\section{BIBLIOGRAPHY}

[1] PEREZ, J. A. G., VILA, F. J. G; ALMENDROS, G., KNICLER, H. The effect off ire on soil organic matter - a review, Enviromental Internacional, v. 30, n. 6, pp. 855-870, Ago. 2004.

[2] KNICKER, H. How does fire affect the nature and stability of soil organic nitrogen and carbon? A review. Biogeochemistry, v. 85, pp. 91-118, Mar. 2007.

[3] SCHMIDT, M, W, I., A. G. NOACK. Black carbon in soils and sediments: Analysis, distribution, implications, and current challenge. Global Biogeochemical Cycles, v. 14, n. 3, pp. 777-793, Set. 2000.

[4] FRANCIOSO, O., CORTES, S. S., BONORA, S., ROLDÁN, M. L. Structural characterization of charcoal size fractions from a burnt Pinus pinea forest by FTIR, Raman and surface-enhanced Raman spectroscopies. Journal of Molecular Structure, v. 994, n. 3, pp. 155-162, Mai. 2011.

[5] ANDRADE, A. M. de, DELLA LUCIA, R. M. Avaliação da higroscopicidade do carvão vegetal e seus efeitos na resistência ao esmagamento. Floresta e Ambiente, v. 2, pp. 20-26, Dez. 1995.

[6] DIAS JÚNIOR, A. F., PIROLA, L. P., TAKEShITA, S., LANA, A. Q., BRITO, J. O., ANDRADE, A. M. Higroscopicity of charcoal produced in different temperatures. Cerne, v. 22, n. 4, pp. 423-430, Dez. 2016.

[7] DIAS JÚNIOR, A. F., BRITO, J. O., ANDRADE, C. R. Granulometric influence on the combustion of charcoal for barbecue. Revista Árvore, v. 39, n. 6, pp. 1-7, Dez. 2015.

[8] LARSON, B. K. Polycyclic aromatic hydrocarbons in smoke a fish. Zeitschrift für. LebensmittelUntersuchung und Forschung, n. 174, pp. 101-107, Jun. 1982.

[9] NISHA, A.R., DINESH KUMAR, V., ARIVUDAINAMBI, S., UMER M., KHAN, M. S. Polycyclic aromatic hydrocarbons in processed meats: a toxicological perspective. Research Journal of Chemistry and Environment, v. 19, n. 6, Jul. 2015. 
[10] LAMMERS, K., KEIL, G. A., DIGHTON, J. Ftir study of the changes in carbohydrate chemistry of three New Jersey pine barrens leaf litters during simulated control burning. Soil Biology and Biochemistry, v. 41, n. 2, pp. 347-347, Fev. 2009.

[11] ALISKE, M. A. Medidas de espectroscopia no infravermelho médio para a determinação do teor de biodiesel em óleo diesel. Dissertação de Mestrado, UFPR, Curitiba, PR. Brasil, 2010.

[12] BORNEMANN, L., WELP, G., BRODOWSKI, S., RADIONOV, A., AMELUNG, W. Rapid assessment of black carbon in soil organic matter using mid-infrared spectroscopy. Organic Geochemistry, v. 39, n. 11, pp. 1537-1544, Nov. 2008.

[13] WANG, R., SUN, R., LIU, G., YOUSAF, B., WU, D., CHEN, J., ZHANG, H. A review of the biogeochemical controls on the occurrence and distribution of polycyclic aromatic compounds (PACs) in coals. Earth Science Reviews, v. 171, pp. 400-418, Ago. 2017.

[14] CADEMARTORI, P. H. G., MiSSIO, A. L., MATTOS, B. D., GATTO, E. D. A. Effect of thermal treatments on technological properties of wood from two Eucalyptus species. Anais da Academia Brasileira de Ciências, v. 87, n. 1, pp. 471-481, Jan. 2015.

[15] ESTEVES, B. A., VELEZ MARQUES, I., DOMINGOS, E. H. PEREIRA. Chemical changes of heat treated pine and Eucalyptus wood monitored by Ftir. Madera, Ciencia y Tecnología, v. 15, n. 2, pp. 245-258, Ago. 2013.

[16] ÖZGENÇ, Ö., DURMAZ, S., BOYACI, I. H., EKSI-KOCAK, E. H. Determination of chemical changes in heat treated wood using ATR-FTIR and FT Raman spectrometry. Molecular and Biomolecular Spectroscopy, n. 171, pp. 395-400, Ago. 2017.

[17] ASSOCIAÇÃO BRASILEIRA DE NORMAS TÉCNICAS. NBR 11941: Madeira - Determinação da densidade básica. Rio de Janeiro, 2003.

[18] TECHNICAL ASSOCIATION OF PULP AND PAPER. TAPPI 222 05-74. Industry lignin in wood. 1974.

[19] TECHNICAL ASSOCIATION OF PULP AND PAPER. TAPPI-12 05-75. Industry preparation of wood for chemical analysis (Including procedures for removal of extractives an determination of moisture content), 1975.

[20] AMERICAN SOCIETY FOR TESTING AND MATERIALS. ASTM D-1764: Standard method for chemical analyses of wood charcoal. Phyladelphia, 1977.

[21] POLETTO, M., A.J. ZATTERA, E R.M.C. SANTANA. Structural differences between wood species: evidence from chemical composition, FTIR spectroscopy and thermogravimetric analysis. Journal of Applied Polymer Science, v. 126, pp. 336-343, Abr. 2012.

[22] COUTO, A.M., PROTÁSIO, T. P., TRUGilho, P. F., NEVES, T. A., SÁ, V. A. Multivariate analysis applied to evaluation of Eucalyptus clones for bioenergy production. Cerne, v. 19, n. 4, pp. 525-533, Out. 2013.

[23] DEMIRBAS, A. Relationships between carbonization temperature and pyrolysis products from biomass. Energy Exploration \& Exploitation, v. 22, n. 6, pp. 411-420, Dez. 2004.

[24] BRITO, J. O. Carvão Vegetal no Brasil: gestões econômicas e ambientais. 64 Ed, São Paulo, Energia, 1990 .

[25] DUBOC, E., COSTA, C. J., VELOSO, R. F., OLIVEIRA, L. dos S., PALUDO, A. Panorama atual da produção de carvão vegetal no Brasil e no Cerrado. Planaltina, DF, Embrapa Cerrados, 2007. (Documentos, 1997).

[26] SINGH S. P., UPADHYAYA, J. S. Studies on the evaluation of cellulosic products by infrared absorption spectroscopy and X-ray diffraction analysis. Cellulose Chemistry and Technology, v. 23, n. 2, pp. 103111, Jan. 1989.

[27] DAVRIEUX, F., ROUSSET, P. L. A. Discrimination of native wood charcoal by infrared spectroscopy. Quimica Nova, v. 33, n. 5, pp. 1093-1097, Set. 2010.

[28] FRIEDEL, R. A. Applied Infrared Spectroscopy. $1^{\circ}$ Ed. New York, Kendall, D. N.: Reinhold, 1966.

[29] GUILANO, M., KISTER, J.; MILLE, J., DOU, H. Spectroscopic studies of charcoals. Analysis, v. 12, n. 4, pp. 201-204, Set. 1984. 
[30] CHENG, X. Y., LI, X. J., XU, K., HUANG, Q. T., SUN, H. N., WU, E. Y. Q. Effect of thermal treatment on functional groups and degree of cellulose crystallinity of Eucalyptus wood (Eucalyptus grandis $\times$ Eucalyptus urophylla). Forest Products Journal, n. 2, pp. 135-140, Nov. 2017.

[31] BOLKER H. I., SOMERVILLE N. G. Infrared spectroscopy of lignins - Part II. Lignins in unbleached pulps. Pulp Paper Mag, v. 64, pp. 187-197, 1963.

[32] DIRCKX, O. Etude du comportement photochimique de I'Abiès grandis sous irradiation solaire. Thèse de $3^{\circ}$ Cycle, Université Nancy, Nancy, France, 1988.

[33] NASSER, A.; HENDAWY, E. Variation in the FTIR spectra of a biomass under impregnation, carbonization and oxidation conditions. Journal of Analytical and Applied Pyrolysis, v. 75, pp. 159-166, Mar. 2006.

[34] MICHELL A. J., INGLE, H. D., STEWART, C. M. Infrared spectra of some woods of taxonomic interest. Wood Sicence and Technollogy, v. 3, pp. 93-99, Set. 1969.

[35] HARRINGTON, K. J., HIGGINS, H. G., MICHELL, A. J. Infrared spectra of Eucalyptus regnans F. Muell. and Pinus radiata d. Don. Holzforschung, v. 18, n. 4, pp. 108-113, Dez. 1964.

[36] FAIX, O., BEINHOFF, O. Ftir spectra of milled wood lignins and lignin polymer models (dhp's) with enhanced resolution obtained by deconvolution. Journal Wood Chemistry and Technollogy, v. 8, n. 4, pp. 505-522, Dez. 1988.

[37] SARKANEN, K. V., CHANG, H. M., ALlAN, G. G. Species variation in lignins. Part II - Conifer lignins. TAPPI, v. 50, pp. 583-587, 1967.

[38] JAGTOYEN, M., DERBYSHIRE, E. F. The transformation of wood to activated carbon. Energeia, v. 4, n. 4, pp. 1-6, Nov. 1993.

[39] NIKONENKO, N. A., BUSLOV, D. K., SUSHKO, N. I., ZHBANKOV, R. G. Spectroscopic manifestation of stretching vibrations of glycosidic linkage in polysaccharides. Journal of Molecular Structure, v. 752, pp. 20-24, Out. 2005.

[40] SANTANA, H., TONI, L. R. M., BENETOLI, L. O. B., ZAIA, C. T. B. V., ROSA M. JR., ZAIA, D. A. M. Effect in glyphosate adsorption on clays and soils heated and characterization by FT-IR spectroscopy. Geoderma, v. 136, pp. 738-750, Dez. 2006.

[41] STEWART, D. Fourier-transform infrared microspectroscopy of plant tissues. Applied Spectroscopy, v. 50, pp. 357-365, Out. 1995.

\section{ORCID}

Ananias Francisco Dias Júnior

Renata Nunes de Oliveira

Xavier Deglise

Natália Dias de Souza

José Otávio Brito https://orcid.org/0000-0001-9974-0567

https://orcid.org/0000-0001-9782-269X

Não informado

https://orcid.org/0000-0002-9322-9669

https://orcid.org/0000-0002-0873-0994 